\title{
Article \\ Flow Intermittency Affects Leaf Decomposition and Benthic Consumer Communities of Alpine Streams: A Case Study along the Po River
}

\author{
Laura Gruppuso $^{1,2, * \mathbb{D}}$, Alberto Doretto ${ }^{2,3} \mathbb{D}$, Elisa Falasco ${ }^{1,2} \mathbb{D}$, Stefano Fenoglio ${ }^{1,2} \mathbb{D}$, Michele Freppaz ${ }^{4}(\mathbb{D}$, \\ Mark Eric Benbow 5,6 (D) and Francesca Bona ${ }^{1,2}$ (D)
}

check for

updates

Citation: Gruppuso, L.; Doretto, A.; Falasco, E.; Fenoglio, S.; Freppaz, M.; Benbow, M.E.; Bona, F. Flow Intermittency Affects Leaf Decomposition and Benthic Consumer Communities of Alpine Streams: A Case Study along the Po River. Water 2022, 14, 258. https:// doi.org/10.3390/w14020258

Academic Editor: Antonella Carosi

Received: 6 December 2021

Accepted: 13 January 2022

Published: 16 January 2022

Publisher's Note: MDPI stays neutral with regard to jurisdictional claims in published maps and institutional affiliations.

Copyright: (C) 2022 by the authors. Licensee MDPI, Basel, Switzerland. This article is an open access article distributed under the terms and conditions of the Creative Commons Attribution (CC BY) license (https:// creativecommons.org/licenses/by/ $4.0 /)$.
1 Department of Life Sciences and Systems Biology, University of Turin, Via Accademia Albertina 13, 10123 Turin, Italy; elisa.falasco@unito.it (E.F.); stefano.fenoglio@unito.it (S.F.); francesca.bona@unito.it (F.B.)

2 Italy Centro per lo Studio dei Fiumi Alpini (ALPSTREAM-Alpine Stream Research Center), 12030 Ostana, Italy; alberto.doretto@uniupo.it

3 Department of Science and Technological Innovation, University of Eastern Piedmont, Viale Teresa Michel 11, 15121 Alessandria, Italy

4 Department of Agricultural, Forest and Food Sciences, University of Turin, Largo Paolo Braccini 2, 10095 Grugliasco, Italy; michele.freppaz@unito.it

5 Department of Entomology, Michigan State University, East Lansing, MI 48823, USA; benbow@msu.edu

6 Department of Osteopathic Medical Specialties, Michigan State University, East Lansing, MI 48823, USA

* Correspondence: laura.gruppuso@unito.it

\begin{abstract}
Streams and rivers are becoming increasingly intermittent in Alpine regions due to the global climate change and related increases of local water abstractions, making it fundamental to investigate the occurrence of supraseasonal drying events and their correlated effects. We aimed to investigate leaf litter decomposition, the $\mathrm{C}: \mathrm{N}$ ratio of the litter, and changes in associated macroinvertebrate communities in three reaches of the Po River: One upstream, consistently perennial, a perennial mid-reach with high hydrological variability, and an intermittent downstream reach. We placed leaf litter bags of two leaf types—chestnut and oak; both showed comparable decomposition rates, but the remaining litter mass was different and was attributed to the $\mathrm{C}: \mathrm{N}$ ratio and palatability. Furthermore, (1) in perennial reaches, leaf litter decomposed faster than in the intermittent ones; (2) in intermittent reaches, the $\mathrm{C}: \mathrm{N}$ ratio showed a decreasing trend in both leaf types, indicating that drying affected the nitrogen consumption, therefore the conditioning phase; (3) associated macroinvertebrate communities were richer and more stable in perennial reaches, where a higher richness and abundance of EPT taxa and shredders was observed. Our results suggest that the variations in the hydrology of mountain streams caused by global climate change could significantly impact on functional processes and biodiversity of benthic communities.
\end{abstract}

Keywords: leaf bags; global climate change; dry rivers; benthic community; CPOM decomposition

\section{Introduction}

Over the last few decades, the phenomenon of riverbed drying in mountain streams has gained increasing attention from researchers [1-3]. In the Italian Alps, effects of climate change such as increasing temperatures and decreasing winter precipitation are also coupled with anthropogenic pressures (i.e., water abstraction) [4,5]. This phenomenon is quite recent in those streams that were previously considered perennial, and its effects must be investigated to fully understand the potential short- and long-term ecological consequences to river and watershed ecosystems. Riverbed drying events can negatively affect ecological processes from primary instream production to allochthonous coarse particulate organic matter (CPOM) decomposition [6]. Since leaf litter decomposition plays a key role in low-order stream nutrient cycling, studying this process has been proposed as a tool to assess river ecosystem quality and functional stream integrity $[7,8]$. Indeed, 
river drying disturbances simplify food webs, making litter processing less efficient [9]. CPOM degradation process is facilitated by both physicochemical (i.e., leaching of soluble compounds and physical abrasion) and biological (i.e., microbial conditioning and invertebrates' fragmentation activity) mechanisms [10-12].

Intrinsic factors, such as litter quality, are also important [13], such as leaf C:N ratio, tannin content, and texture [14,15]. Extrinsic factors also contribute to leaf litter decomposition, including temperature and dissolved nutrient concentrations known to affect bacterial and fungal conditioning [16], with impacts on macroinvertebrate communities [17]. When the flow regime shifts from perennial to intermittent, rheophilic macroinvertebrates, among others, are negatively affected because of reduced lotic habitat availability while lentic taxa increase $[18,19]$. In the Upper Po River catchment, for example, Ephemeroptera, Plecoptera, and Trichoptera (EPT) taxa and those with long, desiccation-sensitive aquatic juvenile life stages decrease in abundance in response to dry conditions $[20,21]$. These events negatively affect shredders as well [22], and their decrease in abundance can further affect trophic interactions and in-stream metabolism [23,24]. Furthermore, the microbial richness can be reduced by water loss, and their activity modified, decreasing leaf litter conditioning important to certain functional feeding groups [25-28]. In mountain piedmont areas, the impacts of supraseasonal drying events (during winter, for example) on benthic communities have been poorly investigated; in such streams, allochthonous CPOM input peaks in autumn and early winter [29], and litter decomposition may be altered by emersion-immersion cycles due to the occurrence of dry periods during this season. Some studies suggest that many macroinvertebrate taxa within these streams lack adaptations to face drought periods [30,31]. To investigate this phenomenon along a significant Alpine river, we analyzed the decomposition process for two different quality leaf types and hypothesized that (1) decomposition rate would differ between leaf types; (2) CPOM breakdown would be faster and with a lower percentage of leaf mass remaining where water was present during throughout the study period; (3) macroinvertebrate communities from the intermittent reach would be less stable and diverse; (4) shredders abundance would be positively related with flowing water presence.

\section{Materials and Methods}

\subsection{Study Site}

The study was carried out along the Po River (Piemonte, western Italian Alps), a major economically and ecologically important watershed in Europe; the headwaters are located in the Cottian Alps, and it is approximately $652 \mathrm{~km}$ long. Three sampling sites were selected along the mountain section of the river (Figure 1): (1) one upstream site, (hereafter Crissolo; $44^{\circ} 42^{\prime} 3.20^{\prime \prime} \mathrm{N}, 7^{\circ} 7^{\prime} 58.98^{\prime \prime} \mathrm{E}$ ), that is perennial and stable; (2) one downstream site (hereafter Sanfront; $44^{\circ} 39^{\prime} 16.65^{\prime \prime}$ N, $7^{\circ} 19^{\prime} 26.62^{\prime \prime}$ E) considered perennial but with high flow variability; (3) an intermittent reach site (hereafter Revello; $44^{\circ} 37^{\prime} 50.35^{\prime \prime} \mathrm{N}, 7^{\circ} 24^{\prime} 25.84^{\prime \prime} \mathrm{E}$ ) where periodic drying events occur. Our knowledge of the occurrence of drying events is supported by our recent research in the study area $[21,32,33]$ and by historical data of the Environmental Regional Agency [34]. The three reaches show different sediment types, according to the River Continuum Concept: Crissolo sampling site is characterized by rocks and boulders, Sanfront by boulders and cobbles, and Revello by cobbles and gravel.

\subsection{Experimental Design}

In each sampling site, we deployed a total of 120 coarse mesh $(1 \mathrm{~cm})$ leaf bags: 60 containing oak leaves (Quercus robur) and 60 chestnut leaves (Castanea sativa). The leaf species were selected because they are the two most abundant in the stream catchment and are characterized by different qualities. Oak is classified as low-quality leaf litter, with coriaceous leaves, while chestnut has high quality, with less tough and more easily decomposable leaves. Each leaf bag contained $5.0 \pm 1.0 \mathrm{~g}$ of dry leaves, collected in October 2018 after the abscission, air dried for 15 days, and stored in dark and dry conditions until the onset of the study. The sampling campaign began on 13 December 2018, with sampling 
occurring every 21 days and ending on 19 April 2019, for a total of 6 sampling dates (Table S1). The seasonal choice was led by the fact that during this season, allochthonous energetic input is particularly significant and, consequently, so is the degradation process. To assess dry periods, water temperature during sampling was logged at $6 \mathrm{~h}$ intervals using $\mathrm{HOBO}^{\circledR}$ TidbiT v2 data loggers (Onset Computer Corporation, Bourne, MA, USA). Conductivity, $\mathrm{pH}$, and dissolved oxygen concentrations were measured on each sampling date using a Hydrolab Quanta probe. At each 21-day sampling date, 10 randomly selected leaf bags of each type were removed with 7 stored in $80 \%$ ethanol before processing and 3 frozen for carbon and nitrogen content analysis. In the laboratory, leaf material was rinsed with water to remove ethanol, oven dried at $105^{\circ} \mathrm{C}$ for $24 \mathrm{~h}$, and then weighed to the nearest $0.1 \mathrm{~g}$ to determine dry mass (i.e., \% residual mass remaining) loss over the sampling dates. Data were expressed as leaf mass remaining.
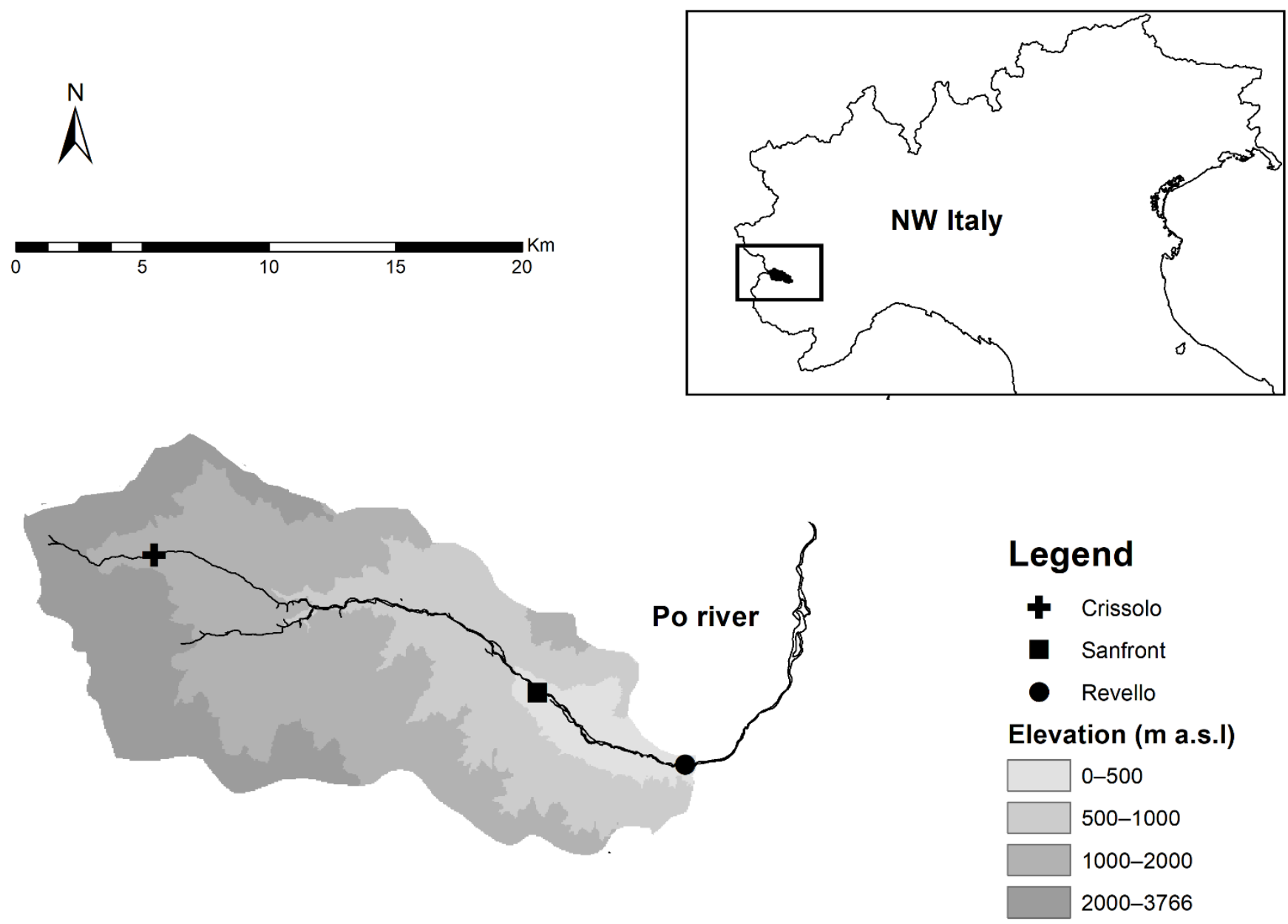

Figure 1. Map of the Po river with the three sampling reaches selected for the experiment.

All macroinvertebrates associated with leaf bags were preserved in $80 \%$ ethanol and identified to family or genus (Plecoptera and Ephemeroptera), following [35-37]. Shredder macroinvertebrate taxa were designated as such, according to [38,39]. The identified shredders were mainly part of the following families: Nemouridae, Leuctridae, Capniidae, Taeniopterygidae, Sericostomatidae, Limnephilidae, Tipulidae, and Gammaridae.

After thawing, the previously frozen samples were rinsed with water, oven dried for $24 \mathrm{~h}$ at $70{ }^{\circ} \mathrm{C}$, and then sent to the laboratory to perform carbon and nitrogen content analyses. Elemental analyses were performed with Elementar Unicube ${ }^{\circledR}$ (CE Instruments NA2100, Rodano, Italy), following the ISO 10694: 1995 protocol. 


\subsection{Data Analysis}

Prior to performing the statistical analyses, data extraction was carried out according to [40], and outliers were removed because they deviated from the general trend: Two for oak (one for total abundance and one for EPT abundance) and three for chestnut (one for total abundance and two for EPT abundance). The final number of samples used for the analyses of oak leaf litter is 124 and 123 of chestnut. For both leaf types, CPOM decomposition was analyzed as described in [41]. The leaf mass remaining, as a \% of residual dry mass for each leaf bag, was log transformed and regressed with time (number of days since the experiment onset), with the slope representing the processing coefficient (i.e., -k) [41]. Due to the temporal dependency of the data, we calculated this slope using linear mixed models (LMM), with \% leaf mass remaining as the dependent variable, day, treatment (i.e., the three sites: perennial, perennial with higher flow variability and intermittent) and their interaction as explanatory variables, and sampling date as random factors. Generalized additive models were used to assess the nonlinear response of the $\mathrm{C}: \mathrm{N}$ ratio over time, expressed in terms of days since the study onset, and sampling date was included as a random factor. For each sampling site, differences among sampling dates (i.e., T1-T6) in taxa richness, total abundance, EPT richness, EPT abundance, and shredder abundance were tested with ANOVA and $\log (x+1)$ transformed data. When significant, pairwise comparisons were performed with the Tukey test (S3-S12). We evaluated heterogeneity in macroinvertebrate community composition using two-dimensional non-metric multidimensional scaling (NMDS) ordination and twoway permutational analysis of variance (PERMANOVA) [42], to test the effects of the sites (Crissolo, Sanfront, and Revello), sampling dates (T1-T6) and their interaction on community compositions. NMDS and PERMANOVA were based on a dissimilarity matrix of BrayCurtis distances calculated using $\log (x+1)$ abundance data. We analyzed the multivariate homogeneity of group dispersions (PERMDISP) as a measure of $\beta$ diversity [43,44]. ANOVA was used to test distances from the PERMDISP group centroid for the communities. Indicator species analysis (i.e., IndVal; Table S13) [45] was used to identify taxa indicative of the three reaches, and thus responsible for compositional differences. All analyses were performed in R [46], by using basic functions and the packages lme4 [47] for LMM; vegan [48] for NMDS; PERMANOVA and PERMDISP for indicspecies [49] for indicator species analysis. Plots were drawn using the packages ggplot2 [50] and ggpubr [51].

\section{Results}

\subsection{Environmental Conditions}

Dataloggers revealed substantial variability in water temperature (from -4.15 to $22.9{ }^{\circ} \mathrm{C}$; mean $\left.\pm \mathrm{SD}: 5.44 \pm 3.16\right)$. In Crissolo and Sanfront reaches had similar temperature variability, while in Revello, there were major fluctuations (Figure S1): Between T1 and T2, for example, water was present but began to decrease to low flow (mean \pm SD: $-0.23 \pm 2.34$ ), while between T3 and T4, temperature drastically increased (5.80 \pm 2.71$)$, and surface water disappeared, leaving the riverbed completely dry and leaf bags exposed to air. At the end of the experiment, water temperature remained high, because of the low flow after the dry period $(11.55 \pm 3.94)$. In the three sampling reaches, water temperature increased over time during the whole experiment. However, in Revello, the sharp fluctuations and higher temperature ranges highlighted the occurrence of drying events and the slow subsequent recovery of flowing water. Physical and chemical values (i.e., conductivity, dissolved oxygen, and $\mathrm{pH}$ ) of the three sampling sites are reported in Table S2.

\subsection{Leaf Decomposition}

For both leaf types, day, treatment (i.e., sites), and their interaction had significant effects on leaf litter decomposition rate (LMM; Table 1). For oak litter, the decomposition rate was highest in Crissolo, where the river is relatively pristine and with a stable, consistent flow (\% of mass remaining mean \pm SD: from $45.13 \pm 0.86$ at $\mathrm{T} 1$ to $4.92 \pm 2.03$ at T6); decomposition rate was similar in Sanfront, although the \% remaining mass was higher than Crissolo (from $49.65 \pm 3.69$ at T1 to $17.14 \pm 5.64$ at T6). Overall, in absence of drying 
events the decomposition process was significantly faster (Figure 2a, Table 1). In Revello, dry events occurred from T3 to T5, and leaf decomposition was significantly slower (from $50.73 \pm 3.02$ at $\mathrm{T} 1$ to $37.81 \pm 2.55$ at T6; Figure 2a, Table 1). There were similar patterns of leaf litter decomposition for chestnut leaves but with lower absolute values of leaf mass remaining (Figure $2 b$, Table 1). In Crissolo, chestnut leaf decomposition was faster and more pronounced than in oak leaves (from $63.82 \pm 3.73$ at T1 to $2.00 \pm 1.38$ at T6), while in Sanfront, the observed values were similar to oak (from $66.19 \pm 3.31$ at T1 to $16.86 \pm 7.75$ at T6). In Revello, chestnut leaf decomposition was slower than in the other two reaches, compared with oak (from $66.05 \pm 4.21$ at $\mathrm{T} 1$ to $58.80 \pm 9.31$ at T6).
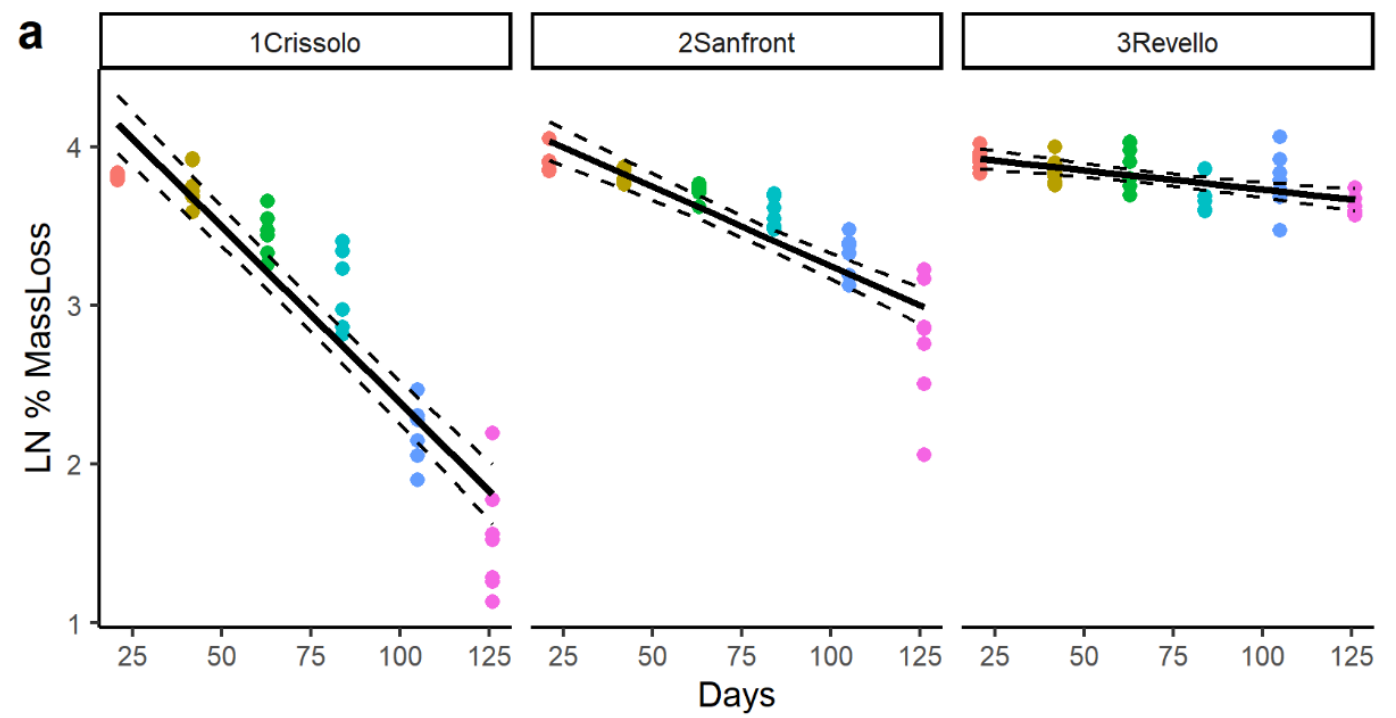

Time
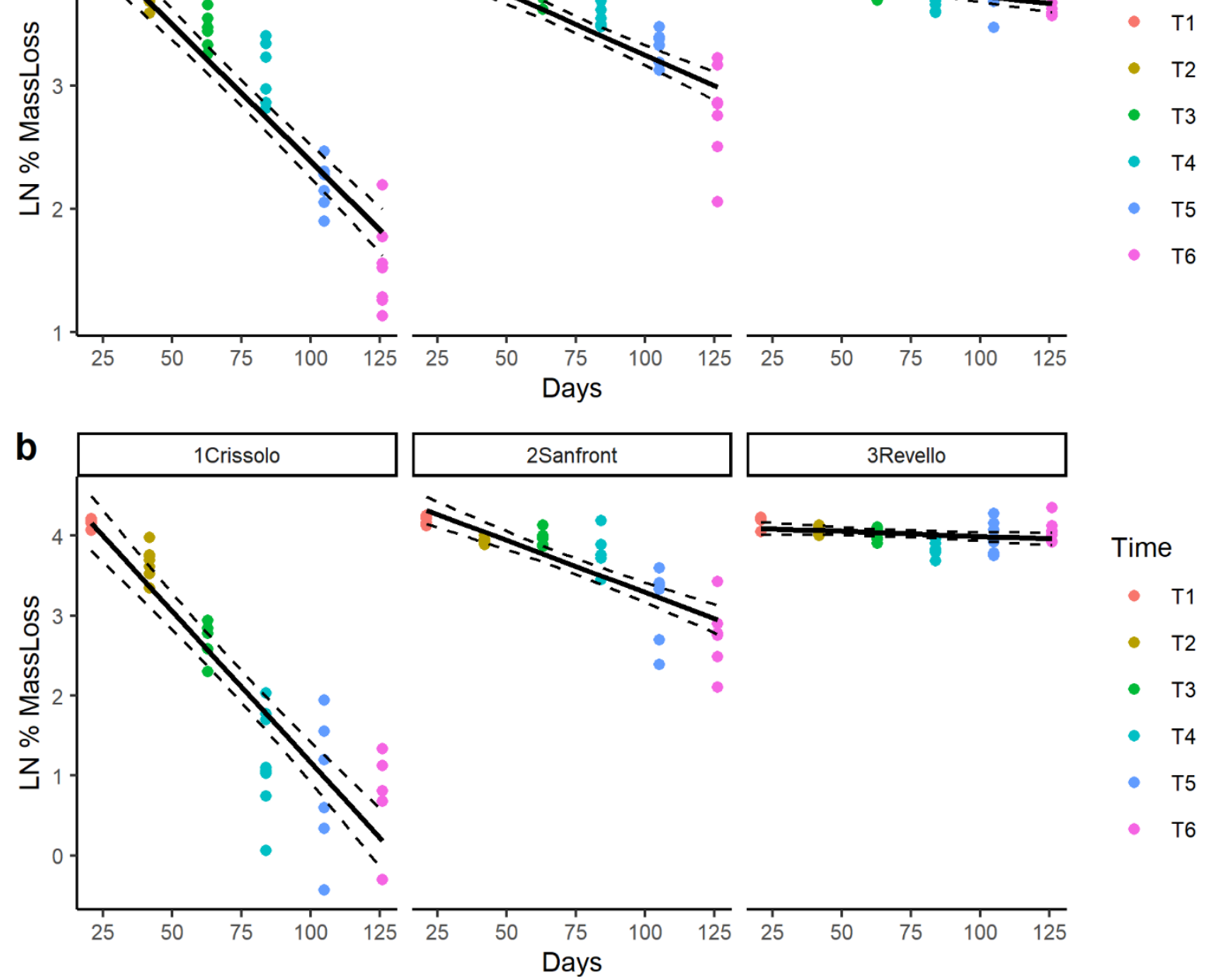

Time

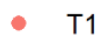

- T2

- T3

- T4

- T5

- T6

Figure 2. LN \% of leaf mass remaining on each sampling date (days 21-126) following deployment (T0), in the three sampling reaches: (a) LMM for oak leaves, slope: -0.02 ; (b) LMM for chestnut leaves, slope: -0.04 .

Significant temporal variation was observed in both leaf types for C:N ratio (Table 2). At the beginning of the experiment, C: $\mathrm{N}$ was $38.98 \pm 0.47$ for oak and $47.64 \pm 0.47$ for chestnut. Regarding oak leaves, the C:N ratio decreased from $\mathrm{T} 1$ to $\mathrm{T} 4$ and increased again between T4 and T5 until the last sampling campaign in Crissolo; in Sanfront, it decreased until T4 and then remained low, while in Revello, it continued to decrease slowly until the end of the experiment (Figure 3a-c). Chestnut leaves showed a different pattern: in 
Crissolo, the C:N ratio decreased until T2, increased again with a peak between $\mathrm{T} 3$ and T4, and then decreased again until the end of it; in Sanfront, it decreased until T3, then increased until T5 and decreased again, while in Revello, it decreased from the beginning to the end of the experiment (Figure $3 \mathrm{~d}-\mathrm{f}$ ).

\section{a Oak}
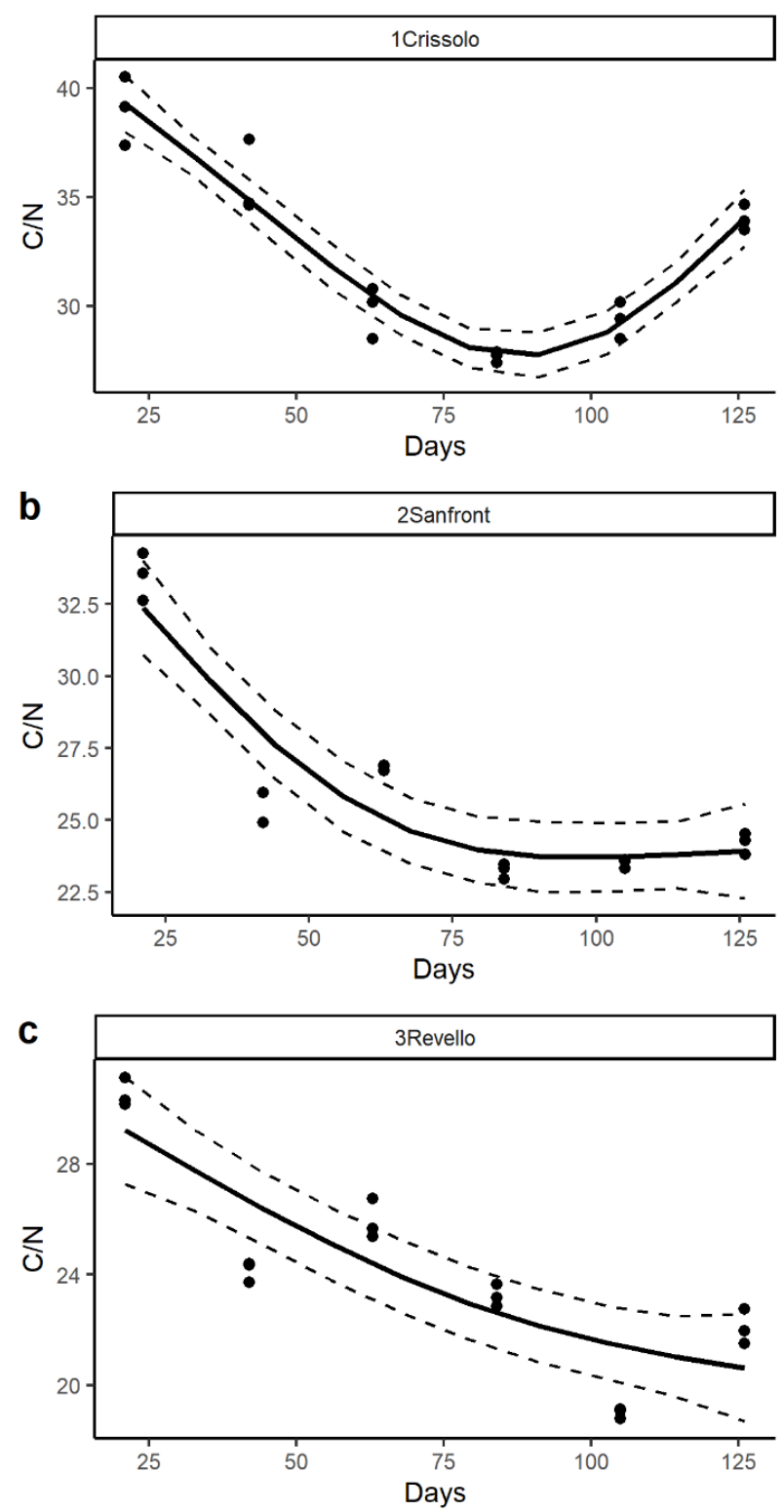

d Chestnut
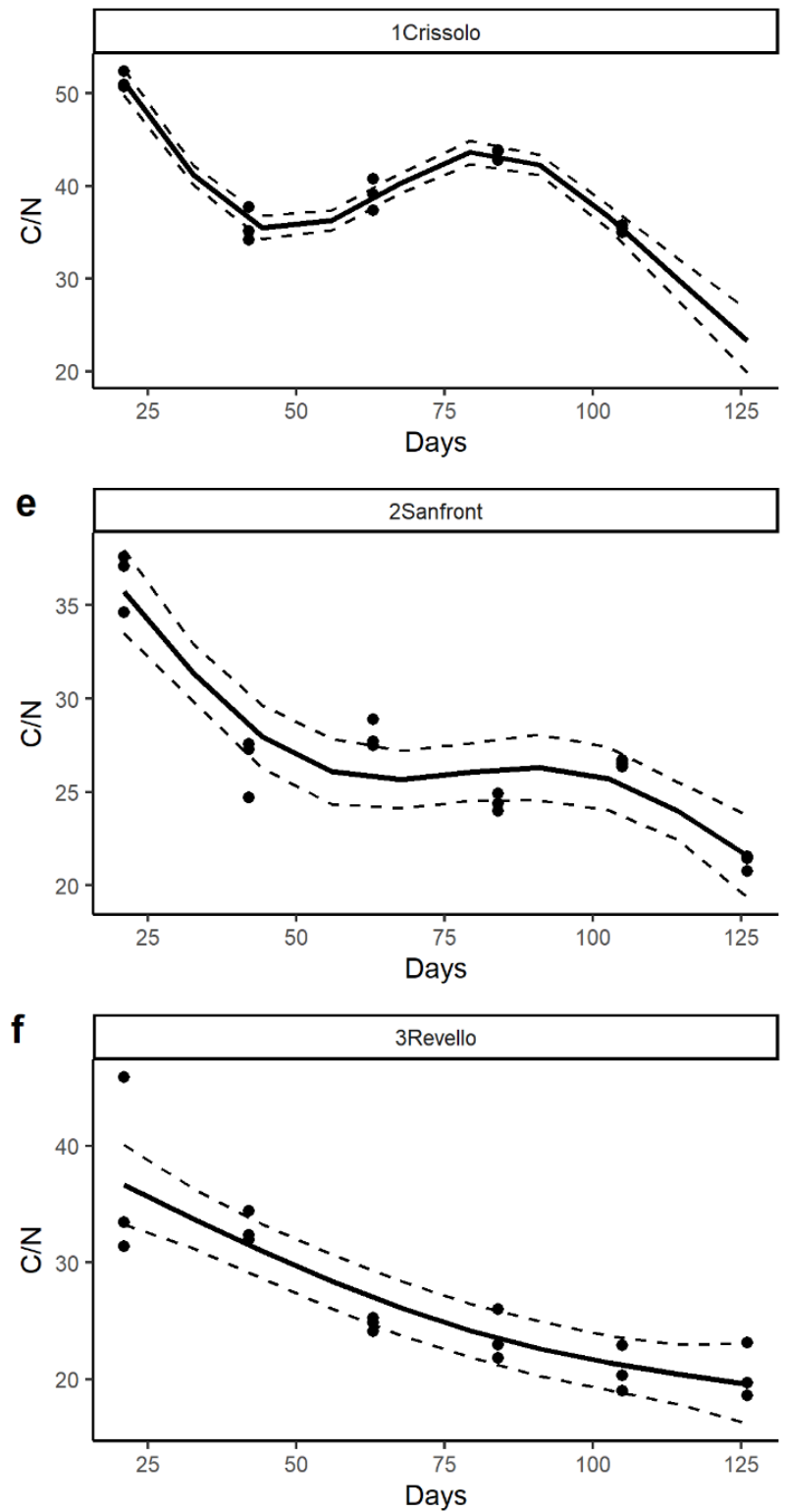

Figure 3. Generalized additive models for C:N ratio in the selected sampling reaches along the Po River: (a-c) Quercus robur; (d-f) Castanea sativa. Black lines represent the predicted values, dashed lines the 95\% confidence interval. On the (d) plot, T6 values are missing, because chestnut leaves were almost completely degraded, and the remaining material was not enough to perform the analysis. 
Table 1. Results of linear mixed models testing the effects of site and day on \% leaf mass remaining for both leaf types. For the categorical variable "site", Site1Crissolo does not appear in the table because it was selected as reference level.

\begin{tabular}{cccccc}
\hline Leaf Type & Variable & Estimate & SE & t & $p$ \\
\hline \multirow{4}{*}{ Quercus robur } & Days & -0.02 & 0.002 & -11.46 & $<0.001$ \\
\cline { 2 - 5 } & Site2Sanfront & -0.36 & 0.10 & -3.55 & $<0.001$ \\
\cline { 2 - 5 } & Site3Revello & -0.61 & 0.10 & -6.02 & $<0.001$ \\
\cline { 2 - 5 } & Days:Site2Sanfront & 0.01 & 0.00 & 9.85 & $<0.001$ \\
\cline { 2 - 5 } & Days:Site3Revello & 0.02 & 0.00 & 15.33 & $<0.001$ \\
\cline { 2 - 5 } Castanea sativa & Days & -0.04 & 0.00 & -18.40 & $<0.001$ \\
\cline { 2 - 5 } & Site2Sanfront & -0.34 & 0.19 & -1.74 & 0.08 \\
\cline { 2 - 5 } & Site3Revello & -0.81 & 0.19 & -4.09 & $<0.001$ \\
\cline { 2 - 5 } & Days:Site2Sanfront & 0.02 & 0.00 & 9.81 & $<0.001$ \\
\cline { 2 - 5 } & Days:Site3Revello & 0.04 & 0.00 & 14.54 & $<0.001$ \\
\hline
\end{tabular}

Table 2. Statistics of the generalized additive models for C:N ratio.

\begin{tabular}{|c|c|c|c|c|c|c|c|}
\hline Metric & Leaf Type & Int & SE & $\mathbf{t}$ & Site & $\mathbf{F}$ & $p$ \\
\hline \multirow{6}{*}{$\mathrm{C}: \mathrm{N}$} & Quercus robur & 27.6303 & 0.5674 & 48.7 & Crissolo & 5.933 & 0.003 \\
\hline & & & & & Sanfront & 7.804 & 0.007 \\
\hline & & & & & Revello & 9.003 & 0.004 \\
\hline & Castanea sativa & 28.9510 & 0.6734 & 42.99 & Crissolo & 32.31 & $<0.001$ \\
\hline & & & & & Sanfront & 14.81 & $<0.001$ \\
\hline & & & & & Revello & 33.35 & $<0.001$ \\
\hline
\end{tabular}

\subsection{Macroinvertebrate Community}

For oak leaf litter, all macroinvertebrate metrics (i.e., taxa richness, total abundance, EPT richness and abundance, shredder abundance) were significantly affected by site, time, and their interaction (ANOVA: $p \leq 0.001$ ). In general, all metrics were highest and most consistent in Crissolo and Sanfront but significantly reduced and variable in Revello (Figure 4). We detected smaller differences when comparing these metrics in Crissolo and Sanfront, while the differences between these two sampling reaches and Revello were more pronounced; for example, total abundance (Figure $4 \mathrm{~b}$ ) was high in Crissolo $(65 \pm 47$ organisms/CPOM $(\mathrm{g}))$ and Sanfront $(69 \pm 56$ organisms/CPOM $(\mathrm{g}))$, while in Revello, this metric was consistently lower $(28 \pm 34$ organisms /CPOM (g)).

For chestnut leaf litter, we observed the same trend: All macroinvertebrates metrics were significantly affected by site, time, and their interaction (ANOVA: $p \leq 0.001$ ). These values were highest and most consistent in Crissolo and Sanfront and significantly reduced and variable in Revello (Figure 5). Total abundance, for example (Figure 5b), showed the highest values in Crissolo (129 \pm 149 individuals /CPOM (g)), high but more variable in Sanfront (75 \pm 82 individuals/CPOM $(\mathrm{g})$ ), and low throughout the whole experiment in Revello (27 \pm 37 individuals/CPOM $(\mathrm{g}))$.

Tukey test comparisons of all the metrics are reported in Supplementary Materials (Tables S3-S12). 
a

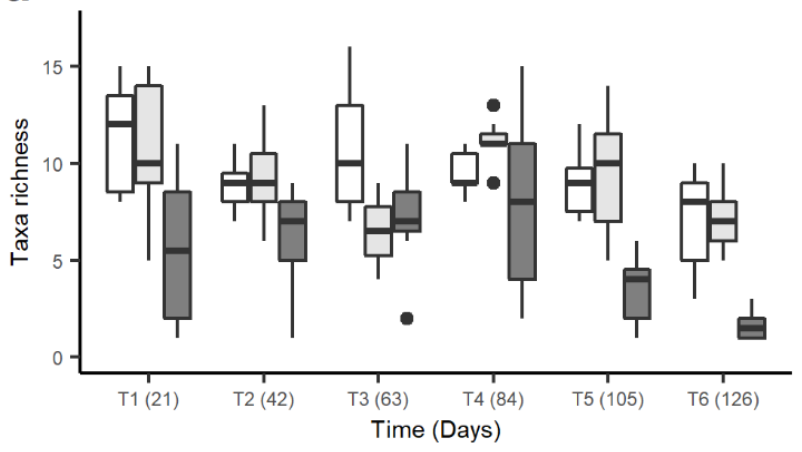

C

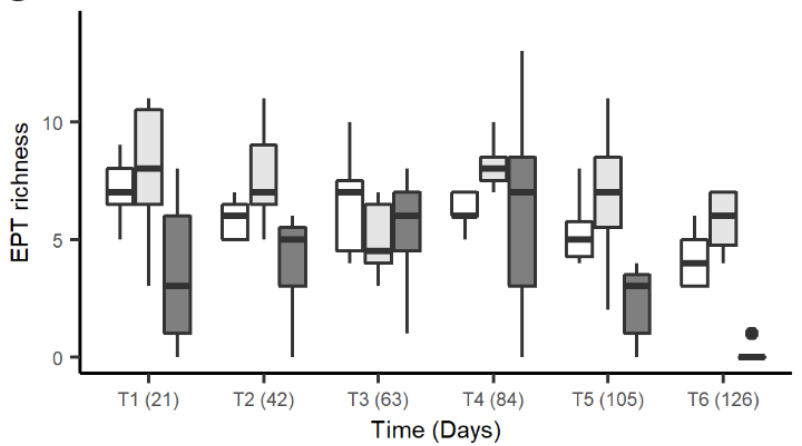

e

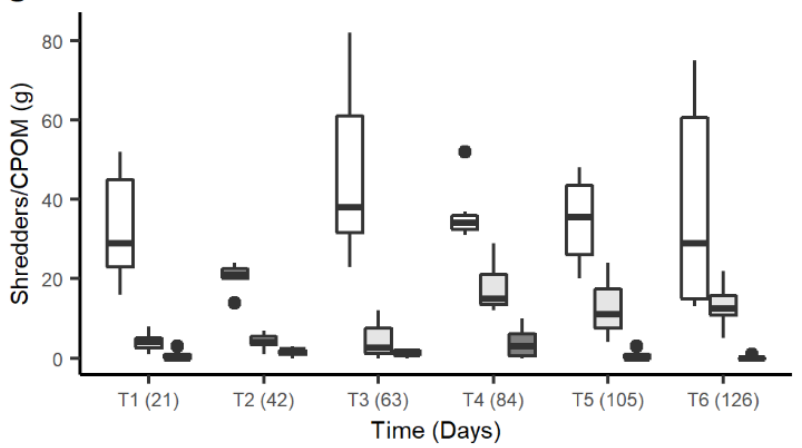

b

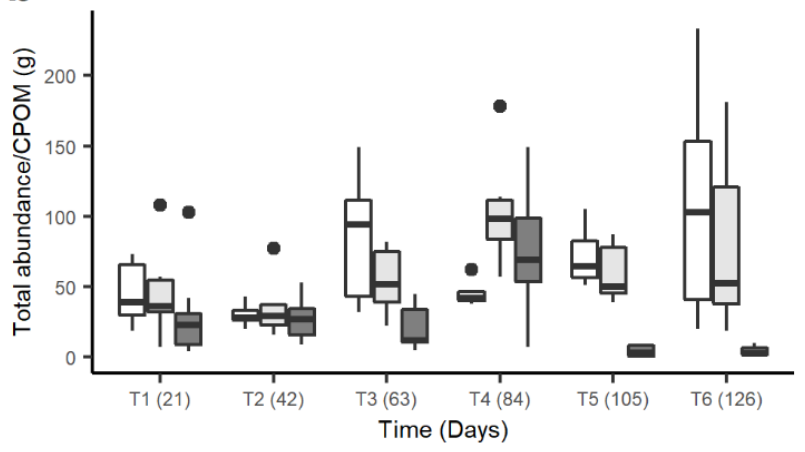

d

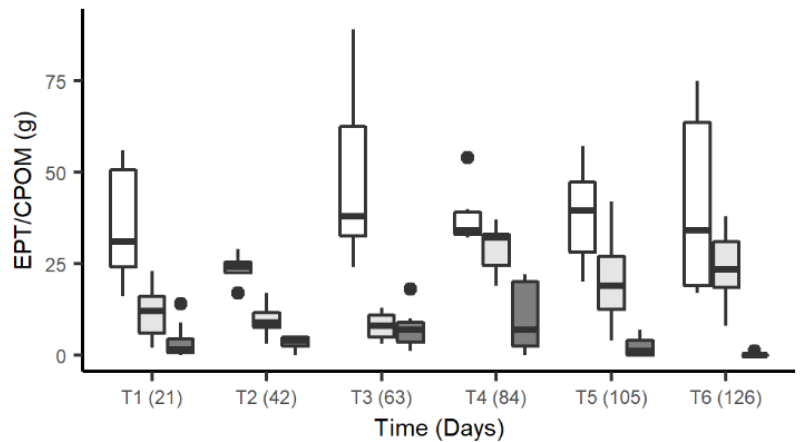

Figure 4. Metrics measured during sampling days in the three sampling reaches for oak leaves: (a) taxa richness; (b) total abundance; (c) EPT richness; (d) EPT abundance; (e) shredders abundance. Black line represents the median value; lower and upper box edges represent first and third quartiles, respectively; vertical lines represent whiskers ( \pm 1.5 interquartile distance).

For both leaf types, community composition was characterized mainly by EPT taxa in Crissolo and Sanfront, and by Diptera in Revello. Regarding oak leaf litter, community composition was significantly affected by time (PERMANOVA; $\mathrm{F}_{5,126}=4 ; p<0.001$ ), treatment (PERMANOVA; $\left.F_{2,126}=34 ; p<0.001\right)$, and their interaction $\left(\right.$ PERMANOVA; $F_{10,126}=4$; $p<0.001)$. In Crissolo, the community was most represented by Nemoura ( $6 \pm 6$ individuals/CPOM (g)), Protonemura ( $4 \pm 5$ individuals), and Limnephilidae (19 \pm 17 individuals), In Sanfront, communities were represented by Amphinemura ( $5 \pm 5$ individuals) Paraleptophlebia ( $1 \pm 2$ individuals) Hydropsychidae ( $2 \pm 3$ individuals), and Rhyacophilidae. For Revello leaf litter, the communities were dominated by Ceratopogonidae (Diptera) ( $1 \pm 2$ individuals/CPOM (g)). For chestnut leaf litter, a similar trend was observed, in which community composition was significantly affected by time (PERMANOVA; $\mathrm{F}_{5,124}=4 ; p<0.001$ ), site (PERMANOVA; $\mathrm{F}_{2,124}=29 ; p<0.001$ ), and their interaction (PERMANOVA; $\mathrm{F}_{10,124}=4 ; p<0.001$ ). The relative proportion of shredder taxa with respect to the other functional feeding groups are 1.06 in Crissolo, 1.025 in Revello, and 1.02 in Sanfront. In Crissolo the community was 
mainly defined by Isoperla ( $1 \pm 1$ individuals/CPOM (g)) Protonemura (6 \pm 11 individuals) and Limnephilidae (46 \pm 93 individuals), while in Sanfront, by Habroleptoides ( $1 \pm 2$ individuals), Paraleptophlebia ( $1 \pm 2$ individuals), and Amphinemura (5 \pm 8 individuals), and in Revello only by Ceratopogonidae $(1 \pm 2$ individuals/CPOM $(\mathrm{g}))$. The results of the indicator species analysis are presented in Table S13, where IndVal and $p$ values are reported. This analysis helps to understand which taxa best characterize each of the three sampling sites. Further information about the macroinvertebrate communities is reported in Tables S14-S16. The NMDS ordination showed similar results for both oak (2D-stress $=0.133$; Figure $6 \mathrm{a})$ and chestnut (2D-stress = 0.123; Figure 6b) —namely, community composition was unique for Crissolo but comparable for Sanfront and Revello at the beginning of the experiment and then, from T3 (after 63 days) onward, Revello showed a more dispersed community than the one of the other two sampling reaches (ANOVA; $p<0.001$ for both leaf types).
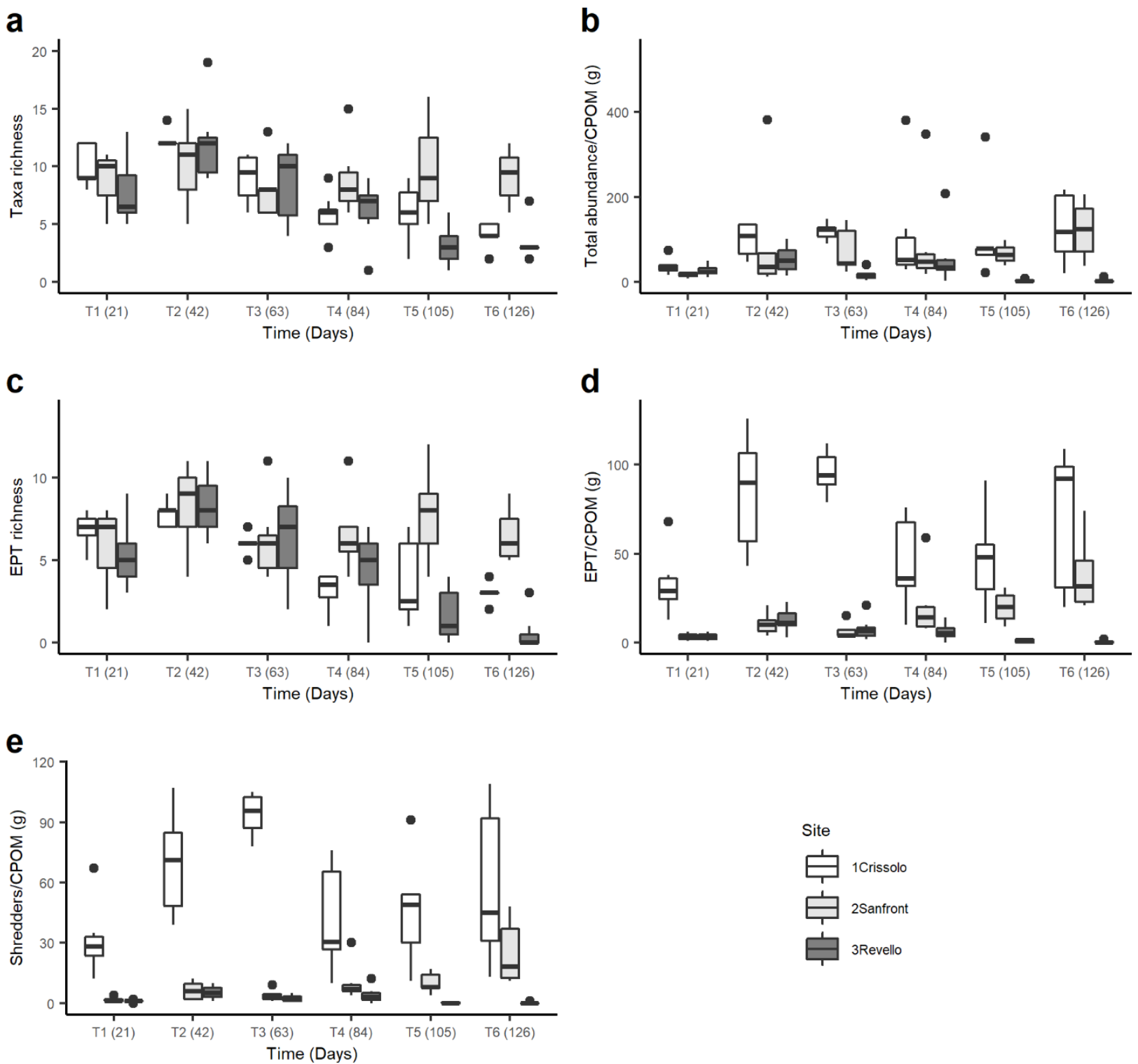

Figure 5. Metrics measured during sampling days in the three sampling reaches for chestnut leaves: (a) taxa richness; (b) total abundance; (c) EPT richness; (d) EPT abundance; (e) shredders abundance. Black line represents the median value; lower and upper box edges represent first and third quartiles, respectively; vertical lines represent whiskers ( \pm 1.5 interquartile distance). 
a

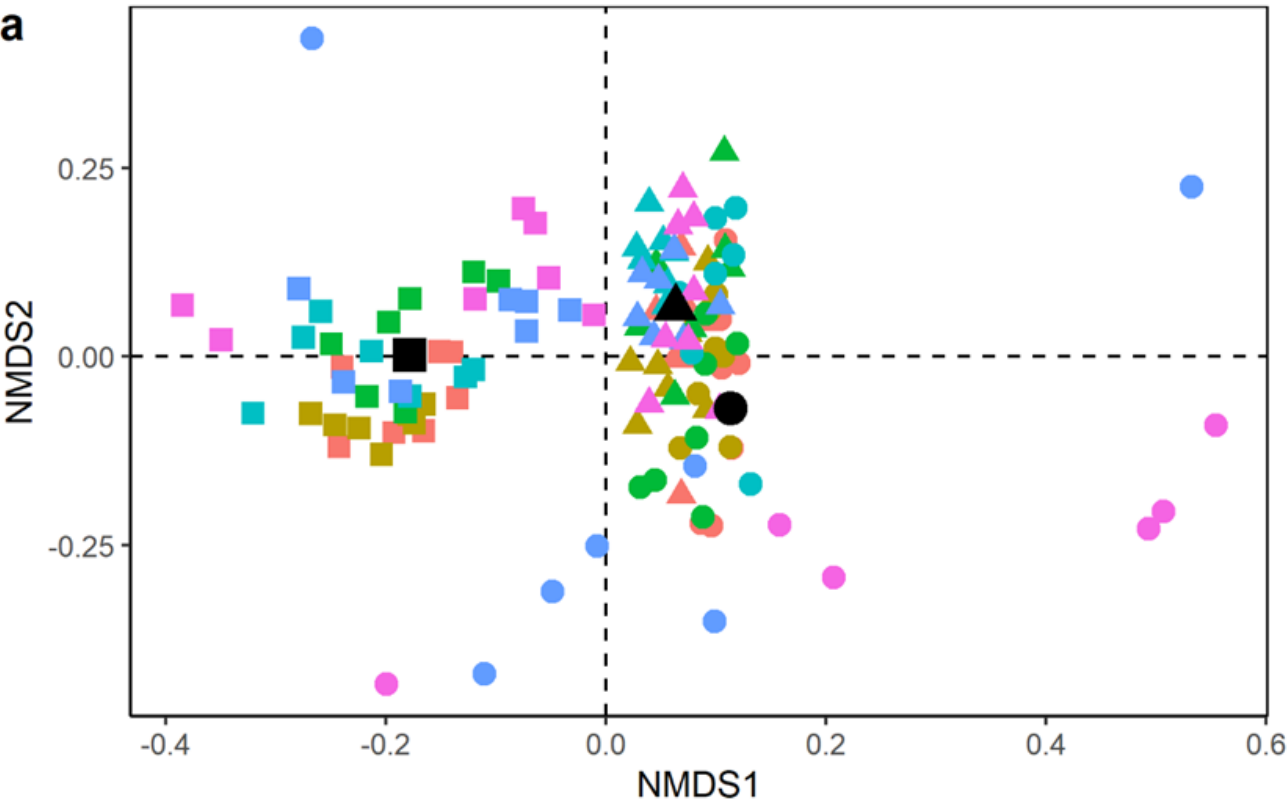

b

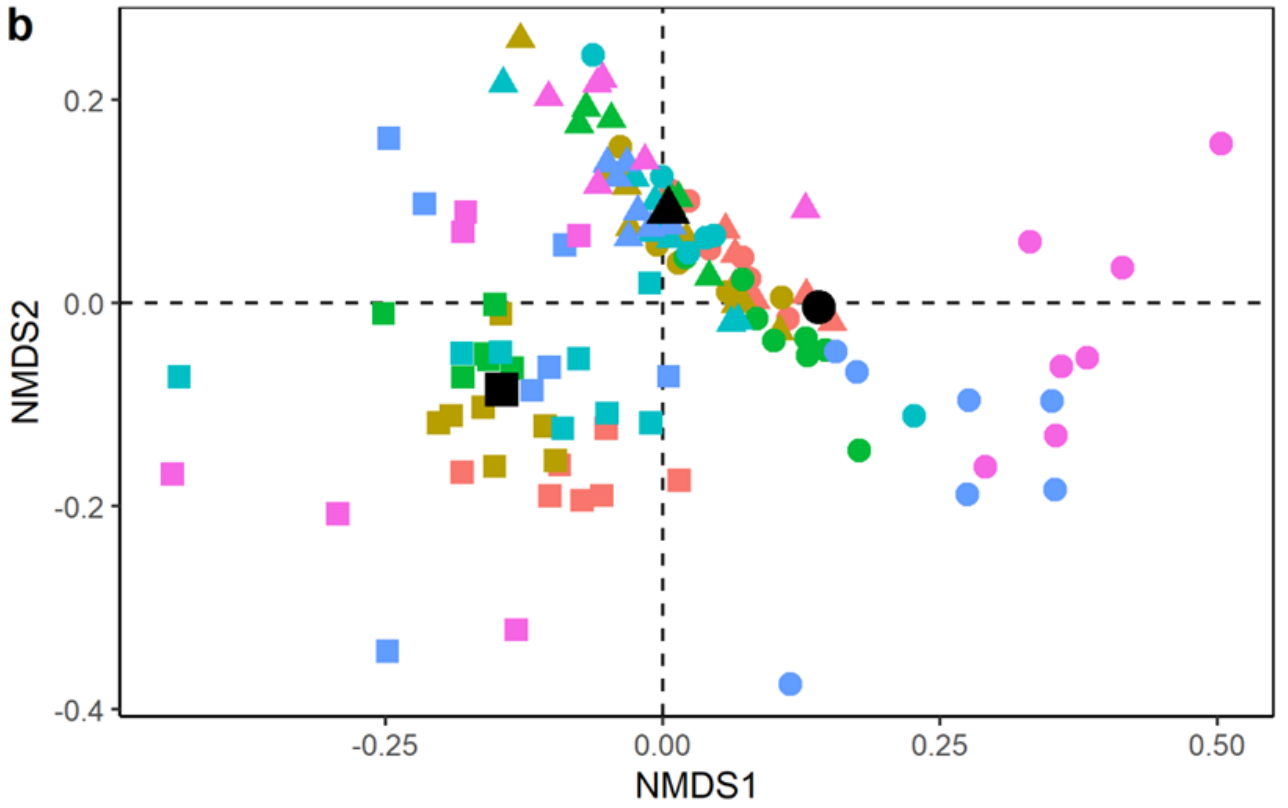

Time

- T1

- T2

- T3

- T4

- T5

- T6

Site

- 1Crissolo

A 2Sanfront

- 3Revello

Time

- T1

- T2

- T3

- T4

- T5

T6

Site

- 1Crissolo

A 2Sanfront

3Revello

Figure 6. Non-metric multidimensional scaling (NMDS) ordination of macroinvertebrate community composition in (a) oak leaves and (b) chestnut leaves; larger black symbols represent centroids for each sampling reach.

\section{Discussion}

Our main aim was to evaluate $\mathrm{CPOM}$ decomposition processes and associated macroinvertebrate communities among river reaches differentially affected by variable flow conditions along an economically and ecological important watershed. The results of this study shed light on the negative effects caused by riverbed drying in mountain streams that were historically considered perennial.

\subsection{Leaf Litter Decomposition}

In this study, we evaluated the effect of supraseasonal dry events, which occur mainly in winter when the input of allochthonous material (mainly deciduous leaves from the autumn season) is higher, on the leaf litter decomposition process [52]. We observed very slow leaf litter decomposition rates associated with a reach that experienced substantial 
riverbed drying over three months, variable water quality conditions during that time, and significant changes in associated macroinvertebrate communities. Indeed, in the sampling reaches that did not experience dry phases (perennial and perennial with flow variability), leaf litter decomposition was faster, with flowing water that likely allowed natural colonization by bacteria and fungi, making leaves more palatable for macroinvertebrates $[53,54]$. In the sampling site where dry events occurred, desiccation may have influenced the conditioning process and, consequently, reduced biotic decomposition activity [55,56]. Leaf quality, however, played an important role in the process: Oak leaves, considered as lowquality leaf litter because of high recalcitrance and nutrient content [57], showed higher leaf mass remaining; however, chestnut leaves, which have been shown to decompose more readily [58,59], had very low leaf mass remaining at the end of the study, especially in the perennial sites. In the Revello site, where dry events occurred, leaf type did not have such a major impact, as all decomposition was very low.

The C:N ratio, even with some differences, decreased in both leaf types and then increased again in Crissolo, the most pristine sampling reach in our study design. Indeed, the nitrogen content is expected to increase in early spring in both chestnut and oak due to higher temperatures [60] and also because of the high conditioning of the leaves surface, which leads to higher consumption of nitrogen [61]. The C: $\mathrm{N}$ decrease in chestnut leaves in Crissolo after its increase was due to the minimum amount of leaf litter remaining in the last two sampling dates when our leaf bags were almost completely decomposed. We hypothesize that the pattern observed for oak's C:N ratio in Crissolo could be the same one detected in chestnut leaf litter but slowed down over time because of the recalcitrant nature of the leaves. In Sanfront, for both leaf types, we observed a decrease in this ratio and then stabilization, even if with slight differences between chestnut and oak, mainly due to their intrinsic nutrient content. Regarding Revello, the sampling reach where dry events occurred, for both leaf types, a decrease in C:N was observed, probably due to the conditioning processes, which were affected by drying. These results suggest that, when the microconsumer conditioning is impacted, higher mineralization of the leaves may occur, due to the oxidation of the organic material exposed to the air. Moreover, some studies highlight that chemical diversification of leaf litter, due to the emersion-immersion variation during flow intermittency, can play an important role in decomposition processes and therefore in better understanding ecosystem functioning [62].

\subsection{Macroinvertebrate Community}

At the beginning of the experiment, macroinvertebrate community composition was similar in Sanfront and Revello sampling reaches, making it possible to directly compare these two sites-one perennial but variable and one intermittent. After 21 colonization days, community composition was very similar; then, as the low flow and dry phase occurred in Revello, the macroinvertebrate community became less diverse and with lower abundances of most taxa. For both leaf types, this was associated with a loss of EPT taxa and medium-to-large-sized univoltine trophic specialists that led to a community dominated by Diptera, mainly Chironomidae and Ceratopogonidae; such results suggest that intermittent flow periods have a large effect on aquatic macroinvertebrates associated with leaf litter that is independent of-and supersedes-the importance of leaf litter quality $[63,64]$. Drift from upstream reaches was probably the main process that facilitated community recovery after drying [65]. Moreover, as demonstrated in previous studies on intermittent rivers and ephemeral streams [66], predators typically increase as flow ceases, and in our experiment, the relative proportion of predators is highest (1.79) in Revello, when compared with Crissolo and Sanfront (1.6 and 1.5, respectively). Along with this increase, shredder macroinvertebrates decrease, as demonstrated by our study. These changes in the trophic chain can affect leaf litter decomposition and therefore river functionality, making previously perennial Alpine streams at severe risk, both in terms of exploring their biodiversity and their ability to efficiently process nutrients, which can influence the general health of these ecosystems. The Crissolo sampling site showed a 
different community composition at the beginning of the experiment, likely explained by its higher elevation and more pristine environmental conditions, where human activities have less impact on the ecosystem. The leaf litter macroinvertebrate community was highly diverse and remained stable through the study. In a study conducted using open-air mesocosms, macroinvertebrate communities showed the same heterogeneity in taxonomic composition when facing flowing and drying phases, compared with the ones in which the continuous flow was maintained [20]; the same results were obtained in another experiment, comparing mesocosms and field data [67], highlighting that this pattern can also be observed in natural conditions, such as in this study. It is important to note that for both leaf types, EPT richness and abundance and shredder abundance were always higher in the perennial sampling sites. EPT taxa are sensitive to flow cessation and drying [68,69], and shredder macroinvertebrates likely colonized leaf litter that was made more palatable by conditioning [70]; furthermore, this process could have been disturbed by dry events, which promote bacteria and fungi desiccation.

\section{Conclusions}

Many studies have been conducted regarding the effects of drying events, mainly in Mediterranean streams [70-72]. In the last decade, research attention has been shifted to those streams that were previously considered perennial but which are now facing dry events more frequently. It has been argued that the communities of these once perennial streams evolved with continuous flow and that they are facing negative consequences with frequent drying events, especially in mountain streams. This explorative research aimed to investigate only one (but widely studied by our research group throughout the years) Alpine stream, with the purpose to increase the current knowledge regarding the possible effects of climate change and human pressures on these threatened ecosystems. Our results clearly showed that the loss of surface running water negatively affected CPOM decomposition, one of the key factors affecting the river ecosystem's functionality. The macroinvertebrate community was also negatively affected, with the loss of specialist/sensitive taxa replaced by more generalists. The differences in decomposition rates were mainly driven by leaf species and quality, but the results are comparable, highlighting the fact that the occurrence of dry events has the same negative effects, despite leaf type. The instream refuges (such as hyporheic sediments) were not investigated in this study, but they certainly function as a support for macroinvertebrate persistence during drying [73,74]. Indeed, further research is needed to understand the long-term effects of drying on these ecosystems, and the capability of recovery if and when flow resumes.

Supplementary Materials: The following supporting information can be downloaded at https: / / www.mdpi.com/article/10.3390/w14020258/s1. Figure S1: Water temperatures recorded at $6 \mathrm{~h}$ intervals and occurrence of dry events in the intermittent reach, based on in-field surveys and water temperatures data; Table S1: Sampling dates in the three selected sampling reaches along the Po River, indicating instream conditions. T0 = leaf bags deployment; T1-T6 sampling campaigns; Table S2: Physical and chemical parameters recorded on each sampling date in the three selected sites; Table S3: Tukey test comparisons for oak leaves taxa richness (S). Significance codes: ${ }^{* *} \leq 0.001 ;{ }^{* *} \leq 0.01$; $* \leq 0.05$; Table S4: Tukey test comparisons for oak leaves total abundance $(\mathrm{N})$. Significance codes: ${ }^{* * *} \leq 0.001 ;{ }^{* *} \leq 0.01 ; * 0.05$; Table S5: Tukey test comparisons for oak leaves EPT richness (EPTS). Significance codes: ${ }^{* * *} \leq 0.001 ;{ }^{* *} \leq 0.01{ }^{*} \leq 0.05$; Table S6: Tukey test comparisons for oak leaves EPT abundance (EPTN). Significance codes: ${ }^{* *} \leq 0.001 ;{ }^{* *} \leq 0.01 ;^{*} \leq 0.05$; Table S7: Tukey test comparisons for oak leaves shredder abundance $(\mathrm{ShN})$. Significance codes: ${ }^{* *} \leq 0.001 ;{ }^{* *} \leq 0.01$; $* \leq 0.05$; Table S8: Tukey test comparisons for chestnut leaves taxa richness (S). Significance codes: $* * * \leq 0.001 ;{ }^{* *} \leq 0.01 ; * \leq 0.05$; Table S9: Tukey test comparisons for chestnut leaves total abundance $(N)$. Significance codes: ${ }^{* *} \leq 0.001 ;{ }^{* *} \leq 0.01{ }^{*} \leq 0.05$; Table S10: Tukey test comparisons for chestnut leaves EPT richness (EPTS). Significance codes: ${ }^{* *} \leq 0.001 ;{ }^{* *} \leq 0.01{ }^{*} \leq 0.05$; Table S11: Tukey test comparisons for chestnut leaves EPT abundance (EPTN). Significance codes: ${ }^{* *} \leq 0.001 ;{ }^{* *} \leq 0.01$; $* \leq 0.05$; Table S12: Tukey test comparisons for chestnut leaves shredder abundance (ShN). Significance codes: ${ }^{* *} \leq 0.001 ;{ }^{* *} \leq 0.01{ }^{*} \leq 0.05$; Table S13: Indicator species analysis results for both 
leaf types. Significance codes: ${ }^{* *} \leq 0.001 ;^{* *} \leq 0.01 *^{*} \leq 0.05$; Table S14: List of macroinvertebrates total abundances and functional feeding groups in Crissolo sampling site regarding both leaf types. $\mathrm{P}=$ Predator; Sh = Shredder Sc = Scraper; F = Filterer Cg = Collector - gatherer; Table S15: List of macroinvertebrates total abundances and functional feeding groups in Sanfront sampling site regarding both leaf types. $\mathrm{P}=$ Predator; $\mathrm{Sh}=$ Shredder; $\mathrm{Sc}=$ Scraper; $\mathrm{F}=$ Filterer; $\mathrm{Cg}=$ Collector-gatherer; Table S16: List of macroinvertebrates total abundances and functional feeding groups in Revello sampling site regarding both leaf types. $\mathrm{P}=$ Predator; $\mathrm{Sh}=$ Shredder; $\mathrm{Sc}=$ Scraper; $\mathrm{F}=$ Filterer; $\mathrm{Cg}=$ Collector - gatherer.

Author Contributions: Conceptualization, L.G. and F.B.; writing-original draft preparation, L.G.; formal analysis, L.G. and A.D.; laboratory work on macroinvertebrates and leaf litter, L.G.; C:N analysis, M.F.; coordination of the fieldwork activities, S.F.; contribution to the fieldwork, E.F.; critical contribution to the analysis and interpretation of the results, M.E.B. All authors set the experimental designs, performed the fieldwork, contributed critically to the drafts. All authors have read and agreed to the published version of the manuscript.

Funding: This study was realized within the framework of the PRIN NOACQUA "Risposte di comuNità e processi ecOsistemici in corsi d'ACQUA soggetti a intermittenza idrologica" project, Code 201572HW8F, funded by Italian MIUR.

Data Availability Statement: The data that support the findings of this study are available from the corresponding author upon reasonable request.

Acknowledgments: The authors would like to thank M. Rappocciolo, M. Titone, and M. Zoppi for their assistance in the field and laboratory and M. Prati for the C:N analyses. The Alpstream-Alpine Stream Research Center and Parco del Monviso are acknowledged for their support during all field activities.

Conflicts of Interest: The authors declare that they have no known competing financial interests that could have appeared to influence the work reported in this paper.

\section{References}

1. Fenoglio, S.; Bo, T.; Cucco, M.; Mercalli, L.; Malacarne, G. Effects of global climate change on freshwater biota: A review with special emphasis on the Italian situation. Ital. J. Zool. 2010, 77, 374-383. [CrossRef]

2. Lencioni, V. Glacial influence and stream macroinvertebrate biodiversity under climate change: Lessons from the Southern Alps. Sci. Total Environ. 2018, 622, 563-575. [CrossRef] [PubMed]

3. Rogora, M.; Frate, L.; Carranza, M.L.; Freppaz, M.; Stanisci, A.; Bertani, I.; Bottarin, R.; Brambilla, A.; Canullo, R.; Carbognani, M.; et al. Assessment of climate change effects on mountain ecosystems through a cross-site analysis in the Alps and Apennines. Sci. Total Environ. 2018, 624, 1429-1442. [CrossRef]

4. Zolezzi, G.; Bellin, A.; Bruno, M.C.; Maiolini, B.; Siviglia, A. Assessing hydrological alterations at multiple temporal scales: Adige River, Italy. Water Resour. Res. 2009, 45, 12. [CrossRef]

5. Ravazzani, G.; Barbero, S.; Salandin, A.; Senatore, A.; Mancini, M. An integrated hydrological model for assessing climate change impacts on water resources of the upper Po river basin. Water Resour. Manag. 2015, 29, 1193-1215. [CrossRef]

6. Monroy, S.; Martínez, A.; López-Rojo, N.; Pérez-Calpe, A.V.; Basaguren, A.; Pozo, J. Structural and functional recovery of macroinvertebrate communities and leaf litter decomposition after a marked drought: Does vegetation type matter? Sci. Total Environ. 2017, 599, 1241-1250. [CrossRef] [PubMed]

7. Gessner, M.O.; Chauvet, E. A case for using litter breakdown to assess functional stream integrity. Ecol. Appl. 2002, 12, 498-510. [CrossRef]

8. Young, R.G.; Matthaei, C.D.; Townsend, C.R. Organic matter breakdown and ecosystem metabolism: Functional indicators for assessing river ecosystem health. J. N. Am. Benthol. Soc. 2008, 27, 605-625. [CrossRef]

9. Ledger, M.E.; Brown, L.E.; Edwards, F.K.; Milner, A.M.; Woodward, G. Drought alters the structure and functioning of complex food webs. Nat. Clim. Chang. 2013, 3, 223-227. [CrossRef]

10. Cummins, K.W. Structure and function of stream ecosystems. BioScience 1974, 24, 631-641. [CrossRef]

11. Leff, L.G. Microbial Ecology of Streams. Encycl. Water Sci. Technol. Soc. 2019, 1-13. [CrossRef]

12. Allan, J.D.; Castillo, M.M.; Capps, K.A. Stream Ecology: Structure and Function of Running Waters; Springer Nature: Cham, Switzerland, 2020.

13. Zhang, M.; Cheng, X.; Geng, Q.; Shi, Z.; Luo, Y.; Xu, X. Leaf litter traits predominantly control litter decomposition in streams worldwide. Glob. Ecol. Biogeogr. 2019, 28, 1469-1486. [CrossRef]

14. Bastias, E.; Ribot, M.; Romaní, A.M.; Mora-Gómez, J.; Sabater, F.; López, P.; Martí, E. Responses of microbially driven leaf litter decomposition to stream nutrients depend on litter quality. Hydrobiologia 2018, 806, 333-346. [CrossRef] 
15. Santschi, F.; Gounand, I.; Harvey, E.; Altermatt, F. Leaf litter diversity and structure of microbial decomposer communities modulate litter decomposition in aquatic systems. Funct. Ecol. 2018, 32, 522-532. [CrossRef]

16. Tank, J.L.; Rosi-Marshall, E.J.; Griffiths, N.A.; Entrekin, S.A.; Stephen, M.L. A review of allochthonous organic matter dynamics and metabolism in streams. J. N. Amer. Benthol. Soc. 2010, 29, 118-146. [CrossRef]

17. Follstad Shah, J.J.; Kominoski, J.S.; Ardón, M.; Dodds, W.K.; Gessner, M.O.; Griffiths, N.A.; Hawkins, C.P.; Johnson, S.L.; Lecerf, A.; LeRoy, C.J.; et al. Global synthesis of the temperature sensitivity of leaf litter breakdown in streams and rivers. Glob. Chang. Biol. 2017, 23, 3064-3075. [CrossRef]

18. Leigh, C.; Bonada, N.; Boulton, A.J.; Hugueny, B.; Larned, S.T.; Vander Vorste, R.; Datry, T. Invertebrate assemblage responses and the dual roles of resistance and resilience to drying in intermittent rivers. Aquat. Sci. 2016, 78, 291-301. [CrossRef]

19. Chessman, B.C. Dissolved-oxygen, current and temperature preferences of stream invertebrates estimated from field distributions: Application to assemblage responses to drought. Hydrobiologia 2018, 809, 141-153. [CrossRef]

20. Doretto, A.; Piano, E.; Falasco, E.; Fenoglio, S.; Bruno, M.C.; Bona, F. Investigating the role of refuges and drift on the resilience of macroinvertebrate communities to drying conditions: An experiment in artificial streams. River Res. Appl. 2018, 34, 777-785. [CrossRef]

21. Piano, E.; Doretto, A.; Falasco, E.; Fenoglio, S.; Gruppuso, L.; Nizzoli, D.; Viaroli, P.; Bona, F. If Alpine streams run dry: The drought memory of benthic communities. Aquat. Sci. 2019, 81, 32. [CrossRef]

22. Tonin, A.M.; Hepp, L.U.; Restello, R.M.; Gonçalves, J.F. Understanding of colonization and breakdown of leaves by invertebrates in a tropical stream is enhanced by using biomass as well as count data. Hydrobiologia 2014, 740, 79-88. [CrossRef]

23. Datry, T.; Corti, R.; Claret, C.; Philippe, M. Flow intermittence controls leaf litter breakdown in a French temporary alluvial river: The "drying memory". Aquat. Sci. 2011, 73, 471-483. [CrossRef]

24. Ledger, M.E.; Edwards, F.K.; Brown, L.E.; Milner, A.M.; Woodward, G.U.Y. Impact of simulated drought on ecosystem biomass production: An experimental test in stream mesocosms. Glob. Chang. Biol. 2011, 17, 2288-2297. [CrossRef]

25. Gonçalves, A.L.; Lírio, A.V.; Graça, M.A.; Canhoto, C. Fungal species diversity affects leaf decomposition after drought. Int. Rev. Hydrobiol. 2016, 101, 78-86. [CrossRef]

26. Gionchetta, G.; Oliva, F.; Menéndez, M.; Lopez Laseras, P.; Romaní, A.M. Key role of streambed moisture and flash storms for microbial resistance and resilience to long-term drought. Freshw. Biol. 2019, 64, 306-322. [CrossRef]

27. Gionchetta, G.; Romaní, A.M.; Oliva, F.; Artigas, J. Distinct responses from bacterial, archaeal and fungal streambed communities to severe hydrological disturbances. Sci. Rep. 2019, 9, 13506. [CrossRef]

28. Arias-Real, R.; Gutiérrez-Cánovas, C.; Munoz, I.; Pascoal, C.; Menéndez, M. Fungal biodiversity mediates the effects of drying on freshwater ecosystem functioning. Ecosystems 2021, 24, 1-15. [CrossRef]

29. Fenoglio, S.; Bo, T.; Cammarata, M.; López-Rodríguez, M.J.; Tierno de Figueroa, J.M. Seasonal variation of allochthonous and autochthonous energy inputs in an alpine stream. J. Limnol. 2015, 74, 272-277. [CrossRef]

30. Calapez, A.R.; Elias, C.L.; Almeida, S.F.; Feio, M.J. Extreme drought effects and recovery patterns in the benthic communities of temperate streams. Limnetica 2014, 33, 281-296. [CrossRef]

31. Elias, C.L.; Calapez, A.R.; Almeida, S.F.; Feio, M.J. From perennial to temporary streams: An extreme drought as a driving force of freshwater communities' traits. Mar. Freshw. Res. 2015, 66, 469-480. [CrossRef]

32. Falasco, E.; Piano, E.; Doretto, A.; Fenoglio, S.; Bona, F. Lentification in Alpine rivers: Patterns of diatom assemblages and functional traits. Aquat. Sci. 2018, 80, 36. [CrossRef]

33. Piano, E.; Doretto, A.; Falasco, E.; Gruppuso, L.; Fenoglio, S.; Bona, F. The role of recurrent dewatering events in shaping ecological niches of scrapers in intermittent Alpine streams. Hydrobiologia 2019, 841, 177-189. [CrossRef]

34. ARPA Agenzia Regionale per la Protezione dell'Ambiente. Idrologia in Piemonte nel 2012; Regione: Piemonte, Italy, $2013 ;$ p. 23. Available online: http:/ / www.arpa.piemonte.it (accessed on 3 November 2021).

35. Campaioli, S.; Ghetti, P.F.; Minelli, A.; Ruffo, S. Manuale per il Riconoscimento dei Macroinvertebrati Delle Acque Dolci Italiane; Provincia Autonoma di Trento: Trento, Italy, 1994; Volume I.

36. Campaioli, S.; Ghetti, P.F.; Minelli, A.; Ruffo, S. Manuale per il Riconoscimento dei Macroinvertebrati Delle Acque Dolci Italiane; Provincia Autonoma di Trento: Trento, Italy, 1999; Volume II.

37. Sansoni, G. Atlante per il Riconoscimento dei Macroinvertebrati dei Corsi D'acqua Italiani; Provincia Autonoma di Trento: Trento, Italy, 1988.

38. Tachet, H.; Bournaud, M.; Richoux, P. Introduction à L'etude des Macroinvertebres des Eaux Douces, 2nd ed.; Villeurbanne, Universiteé de Lyon I: Lyon, France, 1984.

39. Usseglio-Polatera, P.; Bournaud, M.; Richoux, P.; Tachet, H. Biological and ecological traits of benthic freshwater macroinvertebrates: Relationships and definition of groups with similar traits. Freshw. Biol. 2000, 43, 175-205. [CrossRef]

40. Zuur, A.F.; Ieno, E.N.; Elphick, C.S. A protocol for data exploration to avoid common statistical problems. Methods Ecol. Evol. 2010, 1, 3-14. [CrossRef]

41. Benfield, E.F.; Fritz, K.M.; Tiegs, S.D. Leaf-litter breakdown. In Methods in Stream Ecology; Lamberti, G.A., Hauer, F.R., Eds.; Elsevier Academic Press: Cambridge, MA, USA, 2017. [CrossRef]

42. Anderson, M.J. A new method for non-parametric multivariate analysis of variance. Austral Ecol. 2001, 26, 32-46. [CrossRef]

43. Anderson, M.J. Distance-based tests for homogeneity of multivariate dispersions. Biometrics 2006, 62, 245-253. [CrossRef] [PubMed] 
44. Piano, E.; Giuliano, D.; Isaia, M. Islands in cities: Urbanization and fragmentation drive taxonomic and functional variation in ground arthropods. Basic Appl. Ecol. 2020, 43, 86-98. [CrossRef]

45. Dufrêne, M.; Legendre, P. Species assemblages and indicator species: The need for a flexible asymmetrical approach. Ecol. Monogr. 1997, 67, 345-366. [CrossRef]

46. R Core Development Team. R: A Language and Environment for Statistical Computing; R Foundation for Statistical Computing: Vienna, Austria, 2019; Available online: https:/ / www.R-project.org/ (accessed on 4 October 2021).

47. Bates, D.; Machler, M.; Bolker, B. Lme4: Linear Mixed-Effects Models Using S4 Classes, R package version 0.999375-42; 2011. Available online: http:/ / CRAN.R-project.org/package=lme4 (accessed on 4 October 2021).

48. Oksanen, J.; Blanchet, F.G.; Friendly, M.; Kindt, R.; Legendre, P.; McGlinn, D.; Wagner, H. Vegan: Community Ecology Package; R Package Version 2.2-1; 2015. Available online: https: / / cran.rproject.org/package=vegan (accessed on 4 October 2021).

49. Cáceres, M.D.; Legendre, P. Associations between species and groups of sites: Indices and statistical inference. Ecology 2009, 90, 3566-3574. [CrossRef]

50. Wickham, H. Ggplot2: Elegant Graphics for Data Analysis; Springer Nature: New York, NY, USA, 2016. [CrossRef]

51. Kassambara, A. ggpubr: "ggplot2" Based Publication Ready Plots. R Package Version 0.1, 6. 2017. Available online: https: / / cran.r-project.org/package=ggpubr (accessed on 4 October 2021).

52. Northington, R.M.; Webster, J.R. Experimental reductions in stream flow alter litter processing and consumer subsidies in headwater streams. Freshw. Biol. 2017, 62, 737-750. [CrossRef]

53. Duarte, S.; Mora-Gómez, J.; Romaní, A.M.; Cássio, F.; Pascoal, C. Responses of microbial decomposers to drought in streams may depend on the environmental context. Environ. Microbiol. Rep. 2017, 9, 756-765. [CrossRef] [PubMed]

54. Mas-Martí, E.; Sanpera-Calbet, I.; Muñoz, I. Bottom-up effects of streambed drying on consumer performance through changes in resource quality. Aquat. Sci. 2017, 79, 719-731. [CrossRef]

55. Mora-Gómez, J.; Duarte, S.; Cássio, F.; Pascoal, C.; Romaní, A.M. Microbial decomposition is highly sensitive to leaf litter emersion in a permanent temperate stream. Sci. Total Environ. 2018, 621, 486-496. [CrossRef] [PubMed]

56. Simões, S.; Canhoto, C.; Bärlocher, F.; Gonçalves, A.L. Hydrological contraction patterns and duration of drying period shape microbial-mediated litter decomposition. Sci. Total Environ. 2021, 785, 147312. [CrossRef] [PubMed]

57. Santonja, M.; Pellan, L.; Piscart, C. Macroinvertebrate identity mediates the effects of litter quality and microbial conditioning on leaf litter recycling in temperate streams. Ecol. Evol. 2018, 8, 2542-2553. [CrossRef]

58. Ferreira, V.; Chauvet, E.; Canhoto, C. Effects of experimental warming, litter species, and presence of macroinvertebrates on litter decomposition and associated decomposers in a temperate mountain stream. Can. J. Fish. Aquat. Sci. 2015, 72, 206-216. [CrossRef]

59. Júnior, E.S.A.; Martinez, A.; Gonçalves, A.L.; Canhoto, C. Combined effects of freshwater salinization and leaf traits on litter decomposition. Hydrobiologia 2020, 847, 3427-3435. [CrossRef]

60. López, E.S.; Pardo, I.; Felpeto, N. Seasonal differences in green leaf breakdown and nutrient content of deciduous and evergreen tree species and grass in a granitic headwater stream. Hydrobiologia 2001, 464, 51-61. [CrossRef]

61. Villanueva, V.D.; Albariño, R.; Canhoto, C. Detritivores feeding on poor quality food are more sensitive to increased temperatures. Hydrobiologia 2011, 678, 155-165. [CrossRef]

62. Del Campo, R.; Corti, R.; Singer, G. Flow intermittence alters carbon processing in rivers through chemical diversification of leaf litter. Limnol. Oceanogr. Lett. 2020, 6, 232-242. [CrossRef]

63. Di Sabatino, A.; Coscieme, L.; Cristiano, G. Effects of antecedent drying events on structure, composition and functional traits of invertebrate assemblages and leaf-litter breakdown in a former perennial river of Central Apennines (Aterno River, Abruzzo, Central Italy). Ecohydrology 2021, 14, e2358. [CrossRef]

64. Piano, E.; Doretto, A.; Mammola, S.; Falasco, E.; Fenoglio, S.; Bona, F. Taxonomic and functional homogenisation of macroinvertebrate communities in recently intermittent Alpine watercourses. Freshw. Biol. 2020, 65, 2096-2107. [CrossRef]

65. Doretto, A.; Bona, F.; Falasco, E.; Morandini, D.; Piano, E.; Fenoglio, S. Stay with the flow: How macroinvertebrate communities recover during the rewetting phase in Alpine streams affected by an exceptional drought. River Res. Appl. 2020, 36, 91-101. [CrossRef]

66. Stubbington, R.; Bogan, M.T.; Bonada, N.; Boulton, A.J.; Datry, T.; Leigh, C.; Vander Vorste, R. The biota of intermittent rivers and ephemeral streams: Aquatic invertebrates. In Intermittent Rivers and Ephemeral Streams; Academic Press: Cambridge, MA, USA, 2017; pp. 217-243.

67. Gruppuso, L.; Doretto, A.; Piano, E.; Falasco, E.; Bruno, M.C.; Bona, F.; Fenoglio, S. Effects of flow intermittence on ecosystem processes in mountain streams: Are artificial and field experiments comparable? Fundam. Appl. Limnol. 2021, 195, 39-59. [CrossRef]

68. Datry, T.; Larned, S.T.; Fritz, K.M.; Bogan, M.T.; Wood, P.J.; Meyer, E.I.; Santos, A.N. Broad-scale patterns of invertebrate richness and community composition in temporary rivers: Effects of flow intermittence. Ecography 2014, 37, 94-104. [CrossRef]

69. Herbst, D.B.; Cooper, S.D.; Medhurst, R.B.; Wiseman, S.W.; Hunsaker, C.T. Drought ecohydrology alters the structure and function of benthic invertebrate communities in mountain streams. Freshw. Biol. 2019, 64, 886-902. [CrossRef]

70. Piano, E.; Doretto, A.; Falasco, E.; Gruppuso, L.; Bona, F.; Fenoglio, S. Flow intermittency negatively affects three phylogenetically related shredder stoneflies by reducing CPOM availability in recently intermittent Alpine streams in SW-Italian Alps. Hydrobiologia 2020, 847, 4049-4061. [CrossRef] 
71. Acuña, V.; Muñoz, I.; Giorgi, A.; Omella, M.; Sabater, F.; Sabater, S. Drought and postdrought recovery cycles in an intermittent Mediterranean stream: Structural and functional aspects. J. N. Am. Benthol. Soc. 2005, 24, 919-933. [CrossRef]

72. Ylla, I.; Sanpera-Calbet, I.; Vázquez, E.; Romaní, A.M.; Munoz, I.; Butturini, A.; Sabater, S. Organic matter availability during pre-and post-drought periods in a Mediterranean stream. In Global Change and River Ecosystems_Implications for Structure, Function and Ecosystem Services; Springer Nature: Cham, Switzerland, 2010; pp. 217-232.

73. Vicente-Serrano, S.M.; Lopez-Moreno, J.I.; Beguería, S.; Lorenzo-Lacruz, J.; Sanchez-Lorenzo, A.; García-Ruiz, J.M.; Espejo, F. Evidence of increasing drought severity caused by temperature rise in southern Europe. Environ. Res. Lett. 2014, 9, 044001. [CrossRef]

74. Bruno, M.C.; Doretto, A.; Boano, F.; Ridolfi, L.; Fenoglio, S. Role of the Hyporheic Zone in Increasing the Resilience of Mountain Streams Facing Intermittency. Water 2020, 12, 2034. [CrossRef] 